\title{
Old English Literature and Feminist Theory: A State of the Field
}

\author{
Mary Dockray-Miller* \\ Lesley College
}

\begin{abstract}
Feminist and gender scholars working in Anglo-Saxon studies in the past ten years have been asking new and important questions of a variety of Old English and Anglo-Latin texts. Most crucially, this interdisciplinary new work redefines the historiographical paradigms of Anglo-Saxon cultural production and reception so that women must now be regularly included in discussions of Anglo-Saxon cultural agency. This paradigm shift can and should inform broader cultural understandings of the history of gender relations, despite current communication problems among the varied subfields of medieval studies and gender studies. Furthermore, the pedagogy of both medievalists and faculty specializing in later periods must be informed by this shift as well.
\end{abstract}

Feminist and gender scholarship focused on later historical periods has tended to ignore the medieval period in general and feminist work in Anglo-Saxon studies in particular. Judith Bennett's provocative and engaging History Matters argues that feminists and historians focused on the modern periods must acknowledge and include the Middle Ages in their inquiries. Bennett decries the current 'waning of historical depth in feminism' (4), noting that many feminist scholars and activists do not know the full histories of the issues they explore. Her most high-powered example is the 'sticky wage gap' between men and women in Britain, which has remained virtually unchanged for 700 years (5). Ironically, however, Bennett's medieval period seems to be composed entirely of the High and Late Middle Ages; she does not discuss any Anglo-Saxon sources that could provide even more historical depth to her own inquiries. Bennett is by no means alone in this omission, however; historians and critics of the High Middle Ages routinely ignore the early medieval period, as Eileen Joy has meticulously documented. As Joy notes, Tara Williams's 2007 essay in this very journal merely remarks in a footnote that the field of Anglo-Saxon studies is 'outside the scope of this article', while purporting to examine 'the development of feminist criticism and gender studies within medieval literary studies'. ${ }^{1}$ Similarly, the Cambridge History of Medieval English Literature begins after 1066; Beowulf is thus referenced only once in this sweeping 
survey of the field (in Seth Lerer's essay 'Old English and its Afterlife'). Anglo-Saxonists, feminist or not, thus routinely find our chronological field of inquiry excluded from or ignored in other historical discourses.

This exclusion impoverishes both sides of that artificial chronological and linguistic divide, as feminist scholarship in Anglo-Saxon studies is making new and important connections between women and cultural production during the Anglo-Saxon period, connections that should have consequence for our analyses of later periods. The following survey of feminist work in Anglo-Saxon studies in the past ten years ends with a reflection on the current state of the field and suggests fruitful new directions for it as well.

The most recent remarks on the state of the field of feminist Anglo-Saxon studies are Clare Lees's in 'At a Crossroads: Old English and Feminist Criticism'. Now more than ten years old, Lees's essay begins with a survey of early work by feminists in Old English literature, work that 'largely focused on issues of female power, without consideration of the societal structures within which such power operates' (150). Critically similar to Allen Frantzen's 1993 remarks about what he terms the 'women in' phase of feminist criticism (447), Lees's analysis sees the first generation of feminist Old English scholarship to be 'ironically analogous to that history of famous men so criticized by the feminist movement' (149). In their discussions, Lees and Frantzen include books and essays by Jane Chance, Helen Damico, Alexandra Hennessey Olsen, Christine Fell, and Pauline Stafford. Rather than criticize this work from the 1980s for its theoretical shortcomings, however, I would like to valorize it as necessary and revolutionary ground work by disciplinary foremothers - these studies did indeed search in Old English literature and Anglo-Saxon history for women 'whose achievements seemed equivalent to those male figures already well discussed by scholarship' (Lees 148). While much of this early feminist work was certainly not informed by postmodern critical theory, it did force the discipline of Anglo-Saxon studies as a whole to begin to acknowledge women as a legitimate and substantial subject of inquiry for the field.

Frantzen and Lees (along with Martin Irvine, Karma Lochrie, Gillian R. Overing, and others) belong to the first generation of Anglo-Saxon scholars to work with postmodern theory in any substantial way; as such, their work tends to be heavily and consciously theoretically inflected (see, for example, the essay collections edited by Frantzen, Speaking Two Languages [1991], and by Overing and Britton Harwood, Class and Gender in Early English Literature [1994]). To a great extent, Roy Liuzza's 2002 Old English Literature represents this enthusiastic engagement with theory as it collects 21 previously published critical essays focused on literary texts standard to Old English language and literature classes. Many of Liuzza's choices engage postmodern and feminist theory, since the

work of mapping Old English literature is immeasurably assisted by the perspectives offered by contemporary literary criticism ... the fragmented, 
authorless, ideologically charged world of Anglo-Saxon texts is a natural habitat for modern theory. (xiii)

Similarly, Lees and Overing's Double Agents (2001) explicitly rejects the 'women in' paradigms of feminist scholarship of the 1980s ('this is not a book about women in: women in Beowulf, women in other canonical texts' [1]) before engaging with a variety of postmodern theories and Anglo-Saxon texts to argue that 'the denial, silencing, and elision of women's agency in the Anglo-Saxon cultural record at this structural level is so pervasive as to seem utterly naturalized' (172). Lees and Overing read Judith Butler, Toril Moi, and Raymond Williams against Bede, the Exeter Riddles, charters, and other Old English and Anglo-Latin texts in their search for what they term a 'feminist patristics'. While Stephanie Hollis has criticized their reliance on 'proliferating the levels of theorization' rather than engaging with more empirical historical research, Double Agents represents most emphatically the way that the scholarly work of this theoretically focused generation of scholars has academically legitimized feminist and gender-focused work in Anglo-Saxon studies.

That sort of explicit engagement with post-structuralist philosophical and theoretical texts seems to be lessening in the field, however; perhaps Anglo-Saxonists no longer feel the need to defend and discuss so extensively their references to the vocabulary of Jacques Derrida, Michel Foucault, or Judith Butler. The audience's facility with feminist and gender theory may not yet be taken as a given, but feminist explorations of Anglo-Saxon culture no longer need to assume a reader's indifference or even hostility. Elaine Treharne and Greg Walker have argued for such a dramatic change in the field of medieval studies '[w]ithin little more that a single academic generation' (1); while they are discussing the wide-ranging nature of gender-based inquiry throughout interdisciplinary medieval studies, their point is applicable to feminist Anglo-Saxon studies specifically, where inquiry no longer needs to justify its theoretical methodologies. In literary studies at large, the question of whether or not we are 'post-theory' has generated enormous debate (Joy, Callus and Herbrechter, Leitch), and at least one literary theory textbook has a conclusion titled 'Post-Theory' (Selden et al.). Be that as it may, Anglo-Saxon studies is now comfortably post-modern, if not post-theoretical.

That comfort level with feminist inquiry is apparent in the enormous amount of such scholarship published in Anglo-Saxon studies since Lees's 'Crossroads' essay. Essay collections published in medieval studies during the past ten years form something of a Venn diagram with respect to feminist work in Anglo-Saxon culture. Feminist collections that span the Middle Ages chronologically sometimes have one or two essays that discuss the early period; collections that focus on the Anglo-Saxon period sometimes have one or two essays that include feminist approaches and subjects. Carlson and Weisl's Constuctions of Widowhood and Virginity in the Middle 
Ages (1999) is a good example of the first sort; Barnhouse and Withers's The Old English Hexateuch: Aspects and Approaches (2000) of the second. The festschrift, or essay collection in honor of a senior scholar, is also something of a staple in Anglo-Saxon studies. Immediately relevant here is Carol Braun Pasternack and Lisa Weston's Sex and Sexuality in Anglo-Saxon England: Essays in memory of Daniel Gillmore Calder (2004), the only essay collection focused exclusively on issues of sexuality and gender in preConquest England. Its contents

are concerned with how texts of Anglo-Saxon provenance represent potentially reproductive and erotic elements of bodies whether masculine, feminine, or virginal, attracted to the same sex, another sex, or the divine. (xlii)

Pasternack and Weston's introduction to the volume provides an enormously useful and comprehensive overview of the history of sexuality studies in general, in medieval scholarship more particularly, and in Anglo-Saxon studies most specifically. Students tend to find essay collections like Sex and Sexuality Anglo-Saxon England to be most useful as repositories for the textually specific essays they contain rather than as unified wholes; the MLA database does index individual essays from collections, providing a relatively easy way to find updated information about criticism of specific texts. Only a few collections are listed here in the accompanying bibliography, and more are continually appearing.

Work widely dispersed in essay collections and journal articles has become an industry standard, as it were - probably because of the ongoing crisis in scholarly publishing, wherein specialized monographs become less and less cost-effective (MLA Committee, Greco et al.). One recent and notable exception in Old English feminist studies is Stacy Klein's Ruling Women: Queenship and Gender in Anglo-Saxon Literature (2006), which argues 'that Anglo-Saxon writers used legendary royal wives to model cultural ideals of queenship during a historical period in which queenship was itself undergoing profound changes' (4). Klein reads Bede's accounts of queens in the conversion period, Cynewulf's Elene, Beowulf, and two Ælfrician texts as she explores 'the creation of ideologies of gender, family, spirituality, and politics which were both instantiated in and extended far beyond the rarified realm of the royal palace' (4). Klein's major contribution is not simply her readings of the individual texts, but also the ways in which she engages in intertextual and interdisciplinary inquiry. Klein's work spans both chronology and genre, allowing examination of authors' use of queens as cultural signifiers and as 'ideals of normative femininity' (9); she elucidates 'the cultural concerns that are most insistently mediated through legendary royal women . . . issues that cut across boundaries of both social rank and gender' (192). Klein shows that authors used queens to provide cultural critique on a number of issues that are not explicitly about women.

Many of these texts have known male authors (Bede, \#lfric); the scholarly community assumes, with good reason, that the authors of the 
anonymous Old English and Anglo-Latin texts are male as well. In accordance with the Anglo-American project of recovering lost texts authored by women (Showalter), Anne Klinck and others have asked Virginia Woolf's question of some of the vernacular poems: 'Was anonymous a woman?' (the subtitle of one of Klinck's essays). In their anthology, Medieval Woman's Song, Klinck and her co-editor Ann Marie Rasmussen use the term 'female-voiced' rather than 'female-authored' to discuss texts composed in women's voices. The two most obviously relevant Old English texts are the poems Wulf and Eadwacer and The Wife's Lament, both 'female-voiced' and (interestingly enough) both included in the Longman Anthology of Women's Literature, a textbook for women's literature survey courses. Berit Astrom has addressed the desires of critics who define these two texts as female-authored (97) in her history and analysis of the criticism of these two texts. Wulf and Wife, as their titles are often abbreviated, have intrigued and infuriated generations of Old English scholars, feminist or not. While some critics continue to try to 'solve' these female-voiced poems, full of cruces, hapax legomena, and oblique references (John Niles' essay on Wife is the best recent example of this phenomenon), Astrom argues for a multiplicity of co-existing interpretations that point not to a 'resolution' of the text but that 'co-exist and illuminate each other' (113). For all Old English texts - not just Wife and Wulf - Astrom commends what she terms 'metonymic' readings of texts which resist 'conclusion or definitive interpretation' (115). Rather than try to prove that Wulf is or is not female-authored, Astrom asks the interesting question, 'If a male scop recites a poem that speaks in a woman's voice, what effect does that have on the text and the audience?' (98). Instructors or students wishing to pursue this question in some way may want to watch Benjamin Bagby's performance of Beowulf in Old English, now available in DVD format, with a focus on the speech-performances of Wealhpeow.

Astrom's query about the gender of the audience of sung or performed poetry dovetails neatly with the growing body of work on Anglo-Saxon women as audiences of written texts - either as readers of those texts or as listeners who heard the texts read aloud. Linda Olson has argued that medieval women (and men) who were part of an auditory audience of a written text should be considered 'literate' in the sense that they intellectually engaged with the text's contents (3); many of these women can be located in the religious houses that were the bastions of literacy throughout the period. Literary analysis focused on the reading habits of literate religious women provides some of the most exciting interdisciplinary work in current feminist Anglo-Saxon studies.

Stephanie Hollis began a quiet revolution with the publication of Anglo-Saxon Women and the Church in 1992. Her readings of a variety of historical, hagiographical, theological, and literary texts provided a model of interdisciplinary inquiry for feminist exploration of Anglo-Saxon culture. Hollis explores the textual presentations of women from the conversion 
to the Conquest, demonstrating how women's contributions to the project of Christianity were gradually circumscribed; the active female 'soldier of Christ' of the early period had become a much more passive 'bride of the Lamb' by the end of the period (see Hollis 82-108 and throughout). Resistant readings of Bede, Boniface, and others produce a thorough and engaging analysis of the relationship between Anglo-Saxon women and the religious institution that shaped their intellectual and artistic culture.

Scholarly work on the religious culture of Anglo-Saxon women is, of necessity, focused on aristocratic women. Mary Bateson's groundbreaking 1899 essay, 'Origin and History of Double Monasteries', first explored the connections between the various royal families of the Anglo-Saxon kingdoms and the conversion period's 'double monasteries', religious houses for monks and nuns governed by an abbess. The seventh-century double monasteries were important institutions in all the Anglo-Saxon kingdoms (especially in Kent, Northumbria, East Anglia, and Mercia); their abbesses were always members of the royal family who could then act as connections between the church and the state. The double monasteries served as regional centers of government, as hospitals, schools, and libraries, and as powerful church institutions. The double monastery of Whitby, ruled by the abbess Hild in the mid-seventh century, is a good example: Hild hosted the Synod of Whitby, a meeting at which the English heads of the church decided to follow the practices of the Roman rather than the Celtic Church (see discussions of Hild in Hollis; Lees and Overing; Dockray-Miller, Motherhood). Hild's aristocratic and probably royal status ensured her survival in the textual record.

Hollis's book thus examines the women considered important enough to have some sort of a paper trail - the queens and princesses who were subjects of hagiography that has become a focus of recent feminist inquiry in literature as well as other fields. Indeed, the study of 'Old English Literature' has become something of a misnomer in feminist Anglo-Saxon studies, as inquiry includes not just poetry (the most traditional subject of Old English literary study) but hagiography, history, theology, art, and manuscript illustration. An excellent example of this interdisciplinarity is Shari Horner's The Discourse of Enclosure: Representing Women in Old English Literature, which examines poems and saints' lives to argue that 'many Old English texts construct their female subjects by means of a discourse of enclosure derived from the increasingly restrictive conditions of early female monasticism' (6).

Horner ignores the artificially constructed chronological barrier of 1066, as many scholars now do, a change in focus that would have seemed out of place as little as ten years ago. Horner concludes her study with an analysis of the Life of Christina of Markyate, a twelfth-century recluse, making connections between literature more traditionally viewed as 'Old English' and later texts (see introduction in Treharne and Swan as well). 
Even later and more dramatic connections are made by Virginia Blanton in Signs of Devotion (2007), a book-length study of the cult of St Æbelpryð from its inception in the Anglo-Saxon conversion period until the early modern dissolution of the monasteries. Blanton explores Bede's AngloLatin Historia, Old English inscriptions and an illustration in Æpelwold's Benedictional, and a variety of later texts; she shows how the cult of this seventh-century virgin, nun, queen, abbess, and saint functioned throughout the English medieval period in a wide variety of ways for a wide variety of audiences.

More interdisciplinary analyses of Anglo-Saxon religious women and their textual cultures can be found in the work of Crick, Meyer, Ortenberg, and most especially Barbara Yorke, whose Nunneries and the Anglo-Saxon Royal Houses is the culmination of years of work on the relationships between specific religious houses and royal power. During and after the Alfredian period (late ninth century), religious foundations for women were exclusively nunneries - houses only for women; like the earlier double monasteries, these nunneries relied on royal power for land grants, income, protection, and abbesses. Yorke focuses much of her attention on Wilton Abbey, which was an important educational center for royal and aristocratic young women. Edith, daughter of Earl Godwine, was educated there before her marriage to Edward the Confessor, and it is probable that she retired there after his death (84). Yorke's work raises interesting questions about the role of religious institutions in promoting female literacy and education as well as women's relationships with textual culture.

A major part of the current feminist inquiry into Anglo-Saxon literary studies addresses issues of women as readers, copiers, patrons, and creators of texts. Discussion of 'women's reading' and 'women's literacy' in the Middle Ages generally has focused largely on the later periods (for which many more texts are available), and most of the texts under discussion are religious in content. An example focused on Old English is Susan Irvine's examination of marginalia in a twelfth-century homiletic manuscript (London, BL, Cotton Vespasian D.xiv), which suggests that the manuscript was used as private reading material by an English-speaking nun. On a larger scale, Jocelyn Wogan-Browne's Saints' Lives and Women's Literary Culture illustrates the essential relationship between the reading of saints' lives and women's devotional practice in the twelfth and thirteenth centuries. D. H. Green's Women Readers in the Middle Ages provides a broader European context, arguing for the 'domestication of literacy' in the later Middle Ages as literate lay women used prayer books and provided rudimentary reading instruction to their children (257).

That focus on later medieval women's devotional practice has begun to inform analyses of the Anglo-Saxon period as well, however. Sara Foot's Veiled Women has redefined the ways in which we need to think about women and religious practice in late Anglo-Saxon England; Foot argues that the seeming paucity of religious women during and after the Benedictine 
Reform (she terms it 'the disappearance of nuns from Anglo-Saxon England' in her subtitle) is simply a paucity of women in official cloistered institutions. Many more women were deo devotae - devout women who lived in their widows' estates or on their kin group's lands, practicing a religious life in a manner that was almost always undocumented in the extant sources. She argues that these uncloistered women were '[d]ynamic, flexible, inventive, [and] independent' and states that 'hortatory literature was directed towards them as well as to their cloistered sisters'. Foot remarks on the need for further investigation into 'the questions of the education of religious women, and that of female book-ownership in this period' (205-7).

Following a line of inquiry similar to Foot's, Patricia Halpin makes explicit a continuum between the highly literate anchoresses of the later period and the religiousae feminae that lived near the Anglo-Saxon men's religious houses but were not officially affiliated with them. Similarly, Rohini Jayatilaka has raised questions about the use of the Old English versions of the Benedictine Rule by religious women who were not officially enclosed in Benedictine houses. Mary Dockray-Miller has argued that the Vercelli Book, one of the four great manuscripts of Anglo-Saxon poetry, fits neatly into a paradigm of women's devotional reading in the vernacular, as it includes saints' lives, homilies, and religious poetry ('Female Devotion').

Other manuscripts that had female readers at some point in the AngloSaxon period include BL Harley 7653, BL Harley 2965, and BL Royal 2.A.xx, the ninth-century prayer books made for women (Brown); the late tenth-century Salisbury Psalter (Salisbury Cathedral Library MS. 150), in which feminine inflections indicate that it was used by women readers (Morrell 118-20); and the varied versions and Old English translations of the Regularis Concordia and Benedictine Rule made expressly for women readers (Bateson, 'Rules'; Hill, 'Regularis'; 'Making'; Jayatilaka). Catherine Karkov has suggested secular aristocratic women as part of the intended audience of the Genesis texts in Oxford, Bodleian Library MS Junius 11 and London, BL Cotton Claudius B.iv (Karkov, 'Genesis' 207; Text 86). Because of this critical focus on Anglo-Saxon women as readers and audience, the world of women's books in Anglo-Saxon England is suddenly a busy and important arena, containing major texts and manuscripts.

Perhaps most crucially, these feminist analyses of Anglo-Saxon literary culture need to be folded into our undergraduate classes so that the twenty-first century audience of Old English texts realizes that both women and men were textual agents throughout the period. AngloSaxonists need to acknowledge and work within the unhappy reality that most undergraduate English majors will encounter Old English only briefly in anthologized and translated versions of Beowulf and perhaps of Caedmon's Hymn; non-majors will probably not read any Old English literature at all. The medieval feminist community has recently turned its attention to the sophomore-level survey course often called English 
Literature I, with discussion of including more texts by or about women (Artiles). The challenge, of course, is to decide what should be cut if a 'women's' text is added, since neither the semester nor undergraduate cognition is infinitely expandable. Does a focus on Hild in the Caedmon episode introduce the concept of women as textual agents in the Old English period, or does it merely reinforce the tokenism implied by the 'women in' school of early feminist literary criticism? Pedagogy that accomplishes the former while avoiding the latter will be one of the challenges of undergraduate literature faculty in the immediate future.

Building upon the work of disciplinary foremothers of the 1970s and 1980s, and academically legitimized by the work of the postmodern medievalists of the 1990s and the early twenty-first century, current feminist inquiry into Old English literature has thus radically changed our understanding of the landscape of Anglo-Saxon literary culture, which is no longer an almost exclusively masculine preserve. Scholars working in other chronological fields - whether or not their work focuses on issues of gender - need to become informed of this paradigm shift in Anglo-Saxon studies and allow for its implications in their own analyses of literary culture, medieval and beyond.

\section{Short Biography}

Mary Dockray-Miller teaches English in the humanities program at Lesley College in Cambridge, Massachusetts. She is the author of Motherhood and Mothering in Anglo-Saxon England (St Martins, 2000) and editor of The Wilton Chronicle and the Wilton Life of St. Athelthryth (forthcoming from Brepols).

\section{Notes}

* Correspondence address: Humanities Department, Lesley College, 29 Everett St., Cambridge MA 02138, USA. Email: mdockray@lesley.edu.

${ }^{1} \mathrm{I}$ am indebted to Prof. Joy for sharing her work with me before publication.

\section{Works Cited}

Artiles, Erica. 'The Sophomore Survey and the Inclusion of Explicit Women'. Medieval Feminist Forum 43.1 (2007): 35-45.

Åström, Berit. The Politics of Tradition: Examining the History of the Old English Poems the Wife's Lament and Wulf and Eadwacer. Skrifter Från Moderna Språk, 5. Umeå: Institutionen för moderna språk, 2002.

Bagby, Benjamin. Beowulf. New York, NY: Charles Morrow Productions, 2006.

Barnhouse, Rebecca and Benjamin C. Withers. The Old English Hexateuch: Aspects and Approaches. Publications of the Richard Rawlinson Center. Kalamazoo, MI: Medieval Institute Publications/Western Michigan University, 2000.

Bateson, Mary. 'Origin and History of Double Monasteries'. Transactions of the Royal Historical Society n.s. 13 (1899): 137-98.

- ' 'Rules for Monks and Secular Canons after the Revival under King Edgar'. English Historical Review 8 (1894): 690-708. 
Bennett, Judith M. History Matters: Patriarchy and the Challenge of Feminism. Philadelphia, PA: U of Pennsylvania P, 2006.

Blanton, Virginia. Signs of Devotion: The Cult of St. Athelthryth in Medieval England, 695-1615. University Park, PA: Pennsylvania State UP, 2007.

Brown, Michelle. 'Female Book Ownership and Production in Anglo-Saxon England: The Evidence of the Ninth-Century Prayerbooks'. Lexis and Texts in Early English: Studies Presented to Jane Roberts. Eds. Christian Kay and Louise Sylvester. Amsterdam: Rodopi, 2001. $45-67$.

Callus, Ivan and Stefan Herbrechter, eds. Critical Studies: Post-Theory, Culture, Criticism, Vol. 23. New York, NY and Amsterdam: Rodopi, 2004.

Carlson, Cindy L. and Angela Jane Weisl, eds. Constructions of Widowhood and Virginity in the Middle Ages. New York, NY: St Martin's Press, 1999.

Chance, Jane. Woman as Hero in Old English Literature. Syracuse, NY: Syracuse UP, 1986.

Crick, Julia. 'The Wealth, Patronage, and Connections of Women's Houses in Late Anglo-Saxon England'. Bulletin d'histoire benedictine 109 (1999): 154-85.

Damico, Helen. Beowulf's Wealhtheow and the Valkyrie Tradition. Madison, WI: U of Wisconsin P, 1984.

— and Alexandra Hennessey Olsen, eds. New Readings on Women in Old English Literature. Bloomington, IN: Indiana UP, 1990.

DeShazer, Mary K., ed. The Longman Anthology of Women's Literature. New York, NY: Longman, 2001.

Dockray-Miller, Mary. 'Female Devotion and the Vercelli Book'. Philological Quarterly 83 (2004): 337-54.

- Motherhood and Mothering in Anglo-Saxon England. New York, NY: St Martin's Press, 2000.

Fell, Christine E. with Cecily Clark and Elizabeth Williams. Women in Anglo-Saxon England. Bloomington, IN: Indiana UP, 1984.

Foot, Sarah. Veiled Women I: The Disappearance of Nuns from Anglo-Saxon England. Aldershot: Ashgate, 2000.

Frantzen, Allen J., ed. Speaking Two Languages: Traditional Disciplines and Contemporary Theory in Medieval Studies. Albany: State U of New York P, 1991.

—. 'When Women Aren't Enough'. Speculum: A Journal of Medieval Studies 68.2 (1993): $445-71$.

Greco, Albert N. et al. 'The Changing College and University Library Market for University Press Books and Journals: 1997-2004'. Journal of Scholarly Publishing 39 (2007): 1-32.

Green, D. H. Women Readers in the Middle Ages. Cambridge: Cambridge UP, 2007.

Halpin, Patricia. 'Women Religious in Late Anglo-Saxon England'. Haskins Society Journal 6 (1994): 97-110.

Harwood, Britton J. and Gillian R. Overing, eds. Class and Gender in Early English Literature: Intersections. Bloomington, IN: Indiana UP, 1994.

Hill, Joyce. 'Making Women Visible: An Adaptation of the Regularis Concordia in Cambridge, Corpus Christi College Ms. 201'. Conversion and Colonization in Anglo-Saxon England. Eds. Catherine E. Karkov and Nicholas Howe. Tempe, AZ: ACMRS, 2006. 153-67.

—. 'The "Regularis Concordia" and Its Latin and Old English Reflexes'. Revue Benedictine 101 (1991): 299-315.

Hollis, Stephanie. Anglo-Saxon Women and the Church: Sharing a Common Fate. Woodbridge, Suffolk: Boydell Press, 1992.

- 'Review: Double Agents: Women and Clerical Culture in Anglo-Saxon England'. The Medieval Review. University of Michigan University Library, Scholarly Publishing Office, Ann Arbor, 2002. 25 February $2008<$ http://quod.lib.umich.edu:80/t/tmr/>.

Horner, Shari. The Discourse of Enclosure: Representing Women in Old English Literature. Albany, NY: State U of New York P, 2001.

Irvine, Susan. 'The Compilation and Use of Manuscripts Containing Old English in the Twelfth Century'. Rewriting Old English in the Twelfth Century. Eds. Elaine M. Treharne and Mary Swan. Cambridge: Cambridge UP, 2000. 41-61.

Jayatilaka, Rohini. 'The Old English Benedictine Rule: Writing for Women and Men'. AngloSaxon England 32 (2003): 147-88. 
Joy, Eileen. 'Goodbye to All That: The State of My Own Personal Field of Schizoid Anglo-Saxon Studies'. The Heroic Age 11 (May 2008) < http://www.heroicage.org/issues/11/ foruma.php>.

Karkov, Catherine E. 'The Anglo-Saxon Genesis: Text, Illustration, and Audience'. The Old English Hexateuch: Aspects and Approaches. Eds. Rebecca Barnhouse and Benjamin Withers. Kalamazoo, MI: Medieval Institute Publications/Western Michigan University, 2000. 201-38.

- Text and Picture in Anglo-Saxon England: Narrative Strategies in the Junius 11 Manuscript. Cambridge: Cambridge UP, 2001.

Klein, Stacy S. Ruling Women: Queenship and Gender in Anglo-Saxon Literature. Notre Dame, IN: U of Notre Dame P, 2006.

Klinck, Anne. 'Poetic Markers of Gender in Medieval "Woman's Song": Was Anonymous a Woman?' Neophilologus 87 (2003): 339-59.

- and Ann Marie Rasmussen, eds. Medieval Woman's Song: Cross-Cultural Approaches. Philadelphia, PA: U of Pennsylvania P, 2002.

Lees, Clare A. 'At a Crossroads: Old English and Feminist Criticism'. Reading Old English Texts. Ed. Katherine O’Brien O'Keeffe. Cambridge: Cambridge UP, 1997. 146-169.

- and Gillian Overing. Double Agents: Women and Clerical Culture in as England. Philadelphia, PA: U of Pennsylvania P, 2001.

Leitch, Vincent B. 'Theory Ends'. Profession 7 (2005): 122-8.

Liuzza, R. M. Old English Literature: Critical Essays. New Haven, CT: Yale UP, 2001.

Meyer, Marc Anthony. 'The Queen's "Demesne" in Later Anglo-Saxon England'. The Culture of Christendom. Ed. Marc Anthony Meyer. London: Hambledon Press, 1993. 75-113.

MLA Ad Hoc Committee on the Future of Scholarly Publishing. 'The Future of Scholarly Publishing'. Profession n.v. (2002): 172-86.

Morrell, Minnie Cate. A Manual of Old English Biblical Materials. Knoxville, TN: U of Tennessee Press, 1965.

Niles, John D. 'The Problem of the Ending of the Wife's Lament'. Speculum 78 (2003): 1107-50.

Olson, Linda. 'Reading, Writing, and Relationships in Dialogue'. Voices in Dialogue: Reading Women in the Middle Ages. Eds. Linda Olson and Kathryn Kerby-Fulton. Notre Dame, IN: U of Notre Dame P, 2005. 1-32.

Ortenberg, Veronica. 'Virgin Queens: Abbesses and Power in Early Anglo-Saxon England'. Belief and Culture in the Midle Ages: Studies Presented to Henry Mayr-Harting. Eds. Richards Gameson and Henrietta Leyser. Oxford: Oxford UP, 2001. 59-68.

Pasternack, Carol Braun and Lisa M. C. Weston, eds. Sex and Sexuality in Anglo-Saxon England: Essays in Memory of Daniel Gillmore Calder. Tempe, AZ: Arizona Center for Medieval and Renaissance Studies, 2004.

Selden, Raman, Peter Widowson, and Peter Brooker, eds. A Reader's Guide to Contemporary Literary Theory. 5th ed. New York, NY: Longman/Prentice Hall, 2005.

Showalter, Elaine. A Literature of Their Own: British Women Novelists from Bronte to Lessing. Rev. ed. Princeton, NJ: Princeton UP, 1999.

Stafford, Pauline. Queens, Concubines, and Dowagers: The King's Wife in the Early Middle Ages. Leicester: Leicester UP, 1998 [1983].

Treharne, Elaine M. and Mary Swan, eds. Rewriting Old English in the Twelfth Century. Cambridge: Cambridge UP, 2000.

— and Greg Walker. 'Introduction'. Writing Gender and Genre in Medieval Literature. Ed. Elaine M. Treharne. Cambridge: D. S. Brewer, 2002. 1-4.

Wallace, David, ed. The Cambridge History of Medieval English Literature. The New Cambridge History of English Literature. Cambridge: Cambridge UP, 1999.

Williams, Tara. 'Fragments and Foundations: Medieval Texts and the Future of Feminism'. Literature Compass 4.4 (2007): 1003-16.

Withers, Benjamin C. and Jonathan Wilcox, eds. Naked before God: Uncovering the Body in AngloSaxon England. Morgantown, WV: West Virginia UP, 2003.

Wogan-Browne, Jocelyn. Saints' Lives and Women's Literary Culture c.1150-1300: Virginity and Its Authorizations. Oxford: Oxford UP, 2001.

Yorke, Barbara. Nunneries and the Anglo-Saxon Royal Houses. London: Continuum, 2003. 